\title{
Korku Sinemasında Mekan Algısının “Gerçek Mekan” Olgusu Üzerinden Değerlendirilmesi: Session 9 (Son Seans) Filmi*
}

\author{
Belis ÖZTÜRK ${ }^{1}$, Esin SARIMAN ÖZEN ${ }^{2}$
}

Öz

Mimari mekan kullanıcı tarafından fiziksel olarak deneyimlenerek doğrudan kavranır. Buna karşın sinemasal mekanda kullanıcı izleyici durumundadır ve mekanı sinema vasıtasıyla algılar. Mekan algısı kişisel deneyimlemeyle oluşmaz; dolaylı bir görsel deneyime dayanır. İlkdoğan (2020)'a göre "sinemada mekan kavramının karşılık geldiği kavramsal uzamın sınırlarını tam olarak belirlemek güçtür”. Sinemada mekan algısı film içeriği çerçevesinde önceden belirlenmiş/tasarlanmış ve daima izleyiciye gösterilmek istendiği ölçüde sınırlanmış niteliktedir. Algı sinematografik akışa hizmet edecek şekilde manipüle edilir. Böylece bir temsil mekana dönüşür.

Sinemanın "temsil mekanı", sinematografik bütünlük içinde kavramsal bir içerikle açıklanabilir. Burada mekan gerçek bir fizikselliğe karşılık gelmez; sinematografik içeriğin biçimsel uzamını yansıtır.

Büker (2010)'e göre izleyici sinematografik kodlar aracılığı ile anlam üretir ve gerçek ile gerçek olmayan arasında bağ kurar. Bu durumda anlam üretimini subjektif hale getirmektedir. İzleyici kendi gerçek yaşam deneyimleri çerçevesinde aktarılan anlamı yorumlar.

Korku sineması içgüdüsel ve genel bir takım kodları kullanarak anlam üretimini yönlendirir. Ancak kullanıcının kişisel deneyimleri mutlaka anlamlanmada etkin rol oynar. Bu nedenle izleyicinin kendisini durumun dışında ve mesafeli tuttuğu karşılaşma intimalinin olmadığını düşündüğü mekanların (gerçeküstü sinemasal mekanlar) yerine kendisinin gerçek hayatta karşılaşabileceği ya da deneyimlediği mekanların (gerçek sinemasal mekanlar) korku sineması özelinde, daha güçlü bir etki bıraktığı söylenebilir.

Bu bağlamda çalışma, örnek olarak seçilen Session 9 (Son Seans) filminde korku sinemasındaki mekan algısını gerçek mekan olgusu üzerinden değerlendirmektedir.

Anahtar Kelimeler: Sinemasal Mekan, Mekansal Algı, Korku Sineması, Gerçek Mekanlar, Gerçeküstü Mekanlar.

\footnotetext{
${ }^{1}$ Maltepe Üniversitesi, Mimarlık ve Tasarım Fakültesi, İç Mimarlık Bölümü.

${ }^{2}$ Mimar Sinan Güzel Sanatlar Üniversitesi, Mimarlık Fakültesi, iç Mimarlık Bölümü.

* Bu çalışma, Mimar Sinan Güzel Sanatlar Üniversitesi, Fen Bilimleri Enstitüsü, İç Mimarlık Doktora Programı'nda tamamlanan,

danışmanlığını Dr. Öğr. Üyesi Esin SARIMAN ÖZEN’nin yaptığı, “Korku Temalı Filmlerde Gerçek ve Gerçeküstü Mekanların İzleyici

Üzerindeki Etkisinin İncelenmesi" başlıklı doktora tezinden üretilmiştir.

*Igili yazar/Corresponding author: belisozturk@maltepe.edu.tr

Gönderim Tarihi / Received Date: 29.03.2021

Kabul Tarihi / Accepted Date: 05.08.2021
} 


\title{
Evaluation of The Perception of Space in Horror Cinema Based On The "Realistic Space" Phenomenon: Session 9 Film
}

\begin{abstract}
The architectural space is perceived directly by physical experiences of the user. However, in cinematic space, the user is the audience and perceives the space through the cinema. The perception of space is based on an indirect visual experience; not formed by personal experience. According to İlkdoğan (2020) " It is hard to define the exact boundaries of the conceptual space which is corresponding to the concept of space in cinema". Perception of space in cinema is always limited extent in quality for what is desired to be shown to the audience and predetermined/designed within the frame of the movie content. Perception is manipulated to serve the cinematography thus it is transformed into a show space.
\end{abstract}

The "show space" of the cinema, in cinematographic integrity, may be expressed with a conceptual substance. At this point space does not correspond to a real physicality; mirrors the formal space of cinematographic content. To Büker (2010), the audience produces a meaning through cinematographic codes and forges a link between real and unreal so producing a meaning becomes subjective. Audience interprets the meaning as part of their real-life experiences.

Horror cinema shapes the meaning by managing instinctive and certain codes. Nevertheless, personal experiences of the user have an effective role on signification. Therefore, particularly in horror cinema, instead of the spaces have low probability (surrealistic cinematic spaces) to encounter and the audience keeps themselves out of the picture and at a distance, spaces (realistic cinematic spaces) the audience may experience and encounter in their life have more powerful impact.

This study evaluates the perception of space in cinema on the basis of realistic space phenomenon through the referenced movie Session 9.

Keywords: Cinematic Space, Spatial Perception, Horror Cinema, Realistic Spaces, Surrealistic Spaces.

\section{Giriş}

Korku sineması, her ülkenin kendi tarih ve coğrafyasıyla kurduğu bağlar sonucu kendi inanışlarına ve yaşantılarına göre karşılık bulmuş; bununla birlikte temel ve içgüdüsel korku ve kaygılar gibi evrensel olguları da kullanmıştır.

Korku sineması en temelde, insan gözüyle görülmeyen büyük bir dünya olan makro dünyada iyi ile kötü arasındaki mücadeleyi konu edinir. Bu mücadeleyi yansıtırken korku sineması değişik bir takım metaforlar kullanır. Önemli araçlarından biri yarattığı fantastik, gerçeküstü, masalsı bazen de distopik ama gerçekçi dünyalardır. İster gerçeküstü isterse gerçek mekanlar aracılığıyla yaratılmak istenen hayal dünyasının temeli metaforik göstergeler aracılığıyla oluşturulur (Ross, 1984).

Sinema sektöründe kullanılan yeni teknolojiler sayesinde, çağdaş korku sinemasında, korkuyu daha inandırıcı kılan, etkileyici mekân tasarımları ortaya çıkmaktadır. Korku 
sinemasının inandırıcılığı ve seyirciyi içine alabilme becerisi son derece önemlidir. Gerçeküstü/kurgusal mekanların aksine gerçek mekanların hafızaya dayalı tanıdık olma duygusu izleyicinin karakterlerle paralellik/empati kurma, kendini özdeşleştirme eğiliminde tetikleyici rol oynamakta, böylece inandırıcılık düzeyini arttırdığı düşünülmektedir.

\section{Korku Kavramı ve Korku Sineması}

\subsection{Korku Kavramı}

Korku kavramı için genel bir tanım yapılacak olursa, insanın olabilecek olaylara ya da intimallere karşı gösterdiği duygusal tepkiler olduğu söylenebilir (Dönmez, 2018). Korku insanoğlunu üretime sevk ettiği gibi aynı zamanda belli ölçüler içinde insanın bedensel, ruhsal, toplumsal rolünü, denge ve düzen içinde sürdürmesine yardımcı olmaktadır (Köknel, 1998: 17). Bilinçaltına saklanan arzu, istek, duygunun dışavurumu şeklinde de ortaya çıkmaktadır. Bununla birlikte, alışıımışın ve normal olanın alanından sapmalar bir tedirginliğin kuşkunun ya da dehşetin kaynağı olabilir (Bak, 1997: 3). İnsanın sahip olduğu tasarım ve imgelem yeteneği, korkunun temel yaratıcısıdır (Mannoni, 1992: 6). Eğmir' in değindiği Stephen King "korku yazarının uğraşı, okuru geçici olarak çocukluğuna döndürmek" olduğunu belirtmektedir (Eğmir, 2002'den aktaran Aytekin, 2006: 95).

Korku, tehlikeli durumlarda düşünerek hareket edilmesi gerektiği konusunda vücudu uyaran ve koruyan bir sistem gibidir. Bu sistem dikkati ve uyanıklığı gibi diğer işlevleri en üst seviyeye çıkararak potansiyel tehlike durumunda verilecek tepkilerin doğru şekilde yansıtılmasını sağlamaktadır. Korku durumu bir tehlike veya daha önce yaşanılan travmatik bir olay karşısında ortaya çıkmaktadır. Kapalı alan, boğulma ve kilitli kalma, köpeklerden korkma gibi yaşanmışlıklar gibi kişisel tecrübelerden dolayı birtakım korkular oluşabilir. Sigmund Freud'un öğrencilerinden biri olan Otto Rank, korkuların başlıca sebebini doğum anındaki travmaya - bilinen ortamdan bilinmeyen başka bir ortama geçiş ve bir tür terk edilme durumu olduğuna dayandırır.

Gustav Jung (1989) ise, benliği üst ve alt bilinçaltı olarak yorumlamış, üst kısımda kalan bölümü aydınlık anılar, alt kısımdakileri ise karanlıkta kalan anılar olarak değerlendirmiştir. Önyargıların, kişilerin davranışlarının ve korkularının benliğin karanlık yani alt kısmında olduğunu ifade etmiştir (Jung, 1989: 99).

Scognamillo'ya (1996) göre ise korku, gurur ve saygı duyulacak bir duygu değildir; çünkü korkmanın cesaretsizlik ve güçsüzlük olduğuna inanmaktadır. Öte yandan tüm korkular gibi en büyük ve en doğal korkulardan biri olan ölüm korkusunun da yaşanılan süre boyunca insanoğlu ile birlikte olduğunu söylemektedir (Scognamillo, 1996: 151).

Korkuların bir kısmı doğal - somut diğer kısmı ise doğaüstü - soyut özellikler taşımaktadır. Doğal korkular, ölüm, ayrılık, yakınların kayıpları, tabiat olayları gibi içgüdüsel olarak gelişen korkulardır. Hayaletler, vampirler, zombiler gibi açıklanamayan olaylardan kaynaklanan korkular ise; doğaüstü olarak adlandırılmaktadır. Genellikle toplumda korku ve kaygı kavramları aynı olarak bilinsede iki kavram birbirlerinden farklıdır. Korkunun kaynağı nesneye bağlıyken, kaygının kaynağı ise belirsizdir (Şimşek, 2016).

Fobi ise, bir bireyin bir durum, canlı varlık, yer veya nesne hakkında aşırı, mantıksız korku yaşamasına neden olan bir tür anksiyete bozukluğudur. Bir kişinin fobisi olduğunda, korktukları ve karşılaşmak istemedikleri şeylerden kaçınarak hayatlarını 
Korku Sinemasında Mekan Algısının "Gerçek Mekan” Olgusu Üzerinden Değerlendirilmesi: Session 9 (Son Seans) Filmi Evaluation of The Perception of Space in Horror Cinema Based On The "Realistic Space" Phenomenon: Session 9 Film

şekillendirirler. Hayali tehdit, gerçek tehditlerden daha büyüktür. Aynı zamanda fobilerin, teşhis edilebilir zihinsel bozukluklar olduğu da söylenmektedir. Kişi fobisinin kaynağıyla karşı karşıya kaldığında yoğun bir sıkıntı yaşayabilir bu durumda kişinin normal şekilde çalışmasını engelleyebilir ve bazen panik ataklara da neden olabilir.

\subsection{Korku Sineması}

Sinema, korkuyu kendine has yöntemlerle biçimlendirerek işleyen sanat dallarından biridir. Seyirci sinemada, korkunun ve korkuya sebep olan başlıca kavramlardan biri olan ölümün her şeklini görerek onu basit, doğal bir gerçeklik olarak algılamakta ve çocukluk dönemlerinden itibaren gelen ölüm ve kaybetme korkusunu hafifletmeye çalışmaktadır (Oskay, 1994: 66).

Korku sineması hakkında kesin bir tanımlama yapmak çok mümkün değildir. Bunun için temelde korkuyu hedef alan, korku öğelerini barındıran ve korkunun belirleyici unsurlarını taşıyan filmlerin oluşturduğu tür, korku sineması olarak tanımlanabilir.

Ünsal Oskay'a göre "korkunun ucube simgelerinin ve dolayısıyla korkunun temel kaynağı, insanın ölümle yaşama ilişkin en derin ve önemli çocukluk komplekslerinin, ilkel inançlarının varlığı ve uyanık usun kendi yalnızlığından kurtulamamasıdır”. Bu yüzden "insani birçok özelliğini içinde barındıran vampirler, canavarlar ve mumyalar gibi birçok yaratık, insanın öz parçası sayılan kötülük ve günah potansiyelinin kişileşmiş görüntüleri olarak kabul edilir" (Çebi, 2005: 10).

Korku sinemasında, izleyici kendini hem tehlikenin uzağında hem de tehlikeye yakın hisseder. Korku sinemasında izleyici tehlikede olma, öldürülme intimalini bir anlamda filmdeki karakterlere bırakır. Bilinmezden doğan korku duygusu yanında, özel işaretleri ve sembolleri olan bir tür oyun gibi değerlendirir (Tohill ve Tombs, 2005: 36). Korku filmlerinin içeriğinde bir bilinmezlik olduğu gerçeği yatmaktadır. Bu bilinmezlik farklı şekillerde temsil edilip, simgeselleştirilmektedir. Korkular, endişeler, yaşanmış olaylar, eleştirilmek istenen sistem, iktidar gibi olgular çeşitli metaforlarla aktarılmaktadır. "Korku filmlerinin dönemsel olarak farklılaşan temaları, karakterleri vardır; fakat işlev aynıdır. Her film, kendi döneminin gerçekliğinin güdümlenmiş, mistik hale getirilmiş izdüşümünü korkutarak yansıtmaktadır" (Yavuz, 2004: 94).

Sinemanın ilk dönemlerinde ciddiye alınmayan korku sinemasının bu yönü, ona eleştirel ve kuramsal yaklaşımların başladığı 50'lerden sonra keşfedilmiştir. Sinema kuramcıları eski korku filmlerinden başlayarak korku sineması üzerine derin araştırmalar yapmaya yönelmiş, türün özellikleri ve yapısı farklı akademik çalışmalarla ortaya konulmaya çalışılmıştır. 1888 yapımı olan "Roundhay Garden Scene" (Resim 1, Resim 2) dünyadaki ilk film olarak kabul edilmektedir.
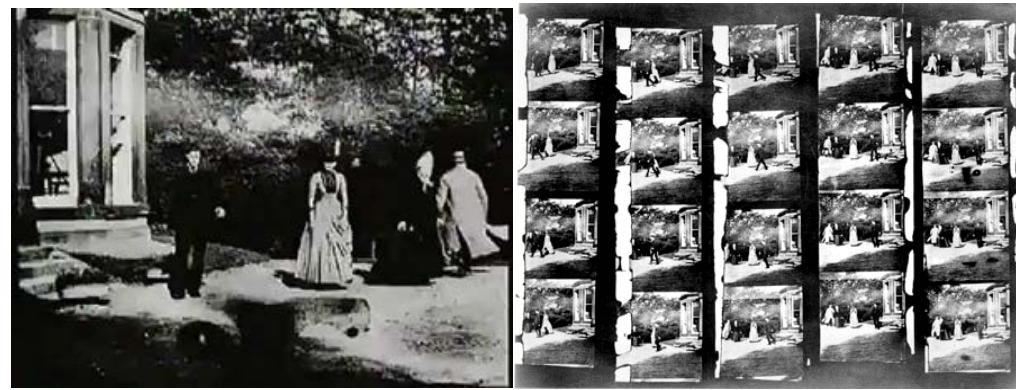

Resim 1. Roundhay Garden Scene (URL 1), (URL 2). 


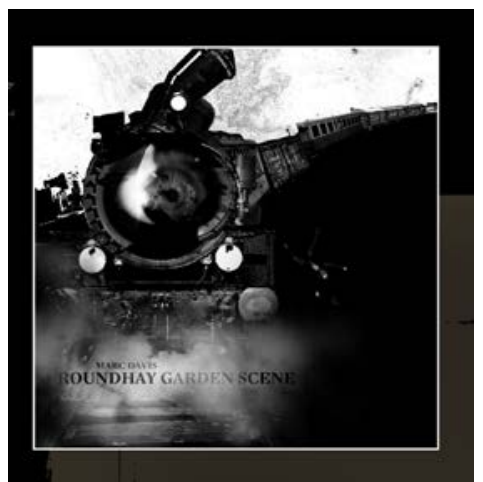

Resim 2. Roundhay Garden Scene (URL 3).

Daha sonra 1896 yapımı olan Georges Méliès'in çektiği iki dakika süren "Le Manoir Du Diable" (Resim 3, Resim 4) adlı film ilk korku filmi olarak tarihe geçmiştir.

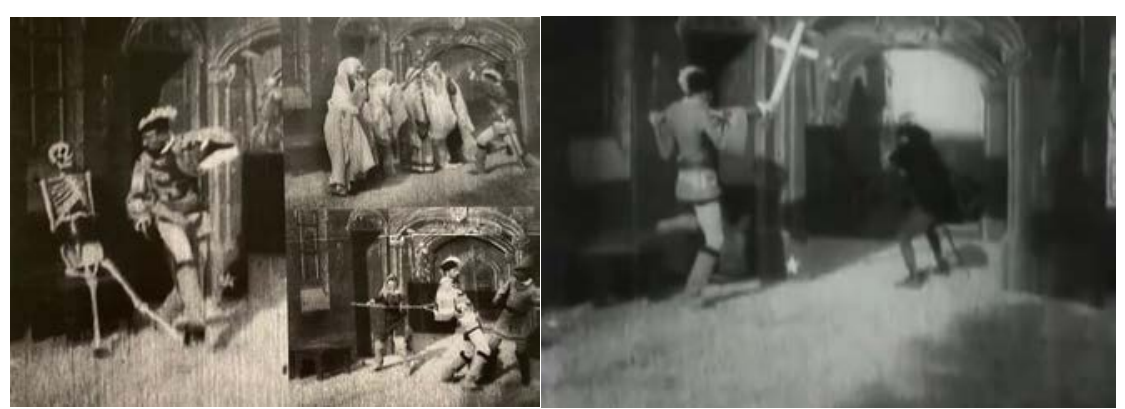

Resim 3. Le Manoir Du Diable (Akbulut, 2012, s.11). Resim 4. Le Manoir Du Diable (URL 4).

Film insanlarla yarasaların karşılaşmasını, kötü ruhları, iskeletleri ve diğer korku öğelerini konu almıştır. 1900'lerin başında, Almanya'da dışavurumcuların ürettiği birçok korku filmi vardır. İnsanları öldüren bir canavar yaratmak için cesetleri kullanan "deli doktor" un hikayesini konu alan ve içeriğinde yaratıcılığın fazla olduğu "Frankenstein" (Resim 5, Resim 6) muhtemelen dünyanın en çok bilinen korku hikayelerinden biri olmuştur.
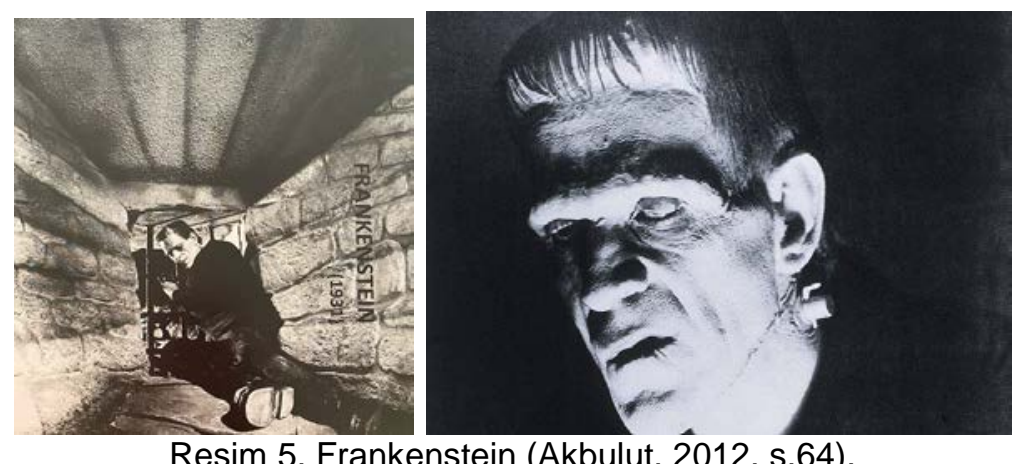

Resim 5. Frankenstein (Akbulut, 2012, s.64). Resim 6. Frankenstein (URL 5).

Modern korku filmleri üzerinde büyük etkisi olan önemli filmlerdenden biri de şizofrenik korku filmlerinin bir modeli olarak görülen "Das Cabinet des Dr. Caligari” dir (Resim 7). 


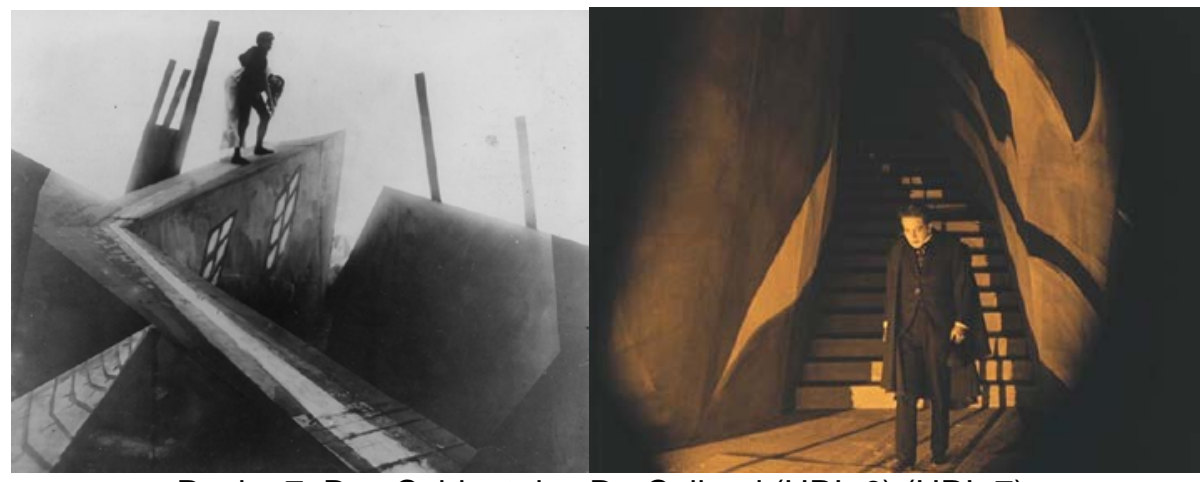

Resim 7. Das Cabinet des Dr. Caligari (URL 6) (URL 7).

Film, hem bir psikolog hem de ikili kimliğe sahip bir katilin hayatını anlatır. Korku sineması tarihi açısından önemli diğer bir film ise 1922 Murnau yapımı Nosferatu'dur. Nosferatu, Bram Stoker'ın Drakula (1897) adlı romanına dayanan sessiz bir filmdir (Resim 8). Filmin izleyici üzerinde uyandırdığı etkinin korkutmaktan çok rahatsız edici olduğu söylenebilir.

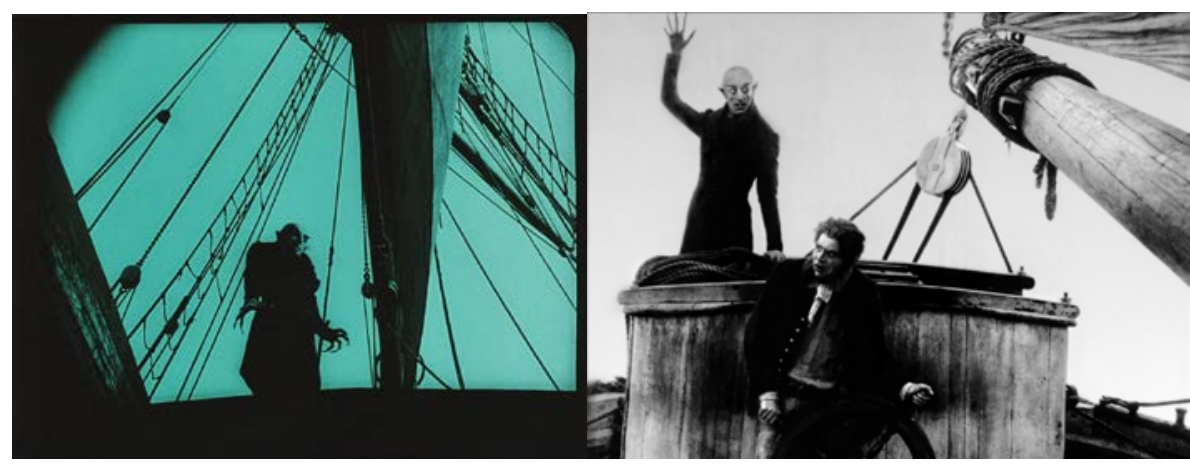

Resim 8. Nosferatu (URL 8) (URL 9).

Bunun oluşmasındaki önemli nedenler fikirlerin, atmosferin ve imgelerin yaratıcı bir değişime sahip olmasıdır. Daha sonra yapılan çoğu vampir filmi bu film temel alınarak oluşturulmuştur (Akbulut, 2012).

Marcia Landy "sinemanın göndermede bulunduğu alanların, resmileşmiş olsun ya da olmasın toplumsal sisteme eklemlenişinin, tabi olmak ve direnmek ile kurallar ve yasaklar arasında ortaya çıkması bakımından homojen olduğunu" söylemektedir (Bak, 2002: 9-10). Örneğin, 19. yüzyılın ikinci yarısında sanayi devriminin yaygınlaştığı dönemde ortaya çıkan Frankenstein ve Drakula gibi filmler kapitalist uygarlığın somutlaşmış simgeleri olarak kabul edilmektedir. Noel Carroll'ın da vurguladığı gibi "korku filmleri bunalım, ekonomik sıkıntılar, savaşlar, hızla artan enflasyon ve ülkedeki karışıklık zamanlarını, toplumda oluşturdukları güçsüzlük ve endişe duygularını etkileyici bir biçimde ifade etmiştir" (Carroll, 2005: 78).

\section{Korku Sinemasında Mekansal Algı}

Çağdaş korku sinemasında teknolojinin son imkânları da kullanılarak, korkuyu inandırıcı kılan mekân tasarımları ile etkileyici bir atmosfer yaratmak olanaklı hale gelmektedir. Korku sinemasının inandırıcılığı ve seyirciyi içine katabilme becerisi son derece önemlidir. Farklı olgular ele alınarak modern dünyanın modern korkuları gerçek ya da gerçeküstü/kurmaca mekan kurgusunun inandırıcılığının sağladığı avantajlar ile işlenmektedir. 
Korku sinemasında, mekanını kullanımı öngörülemez ve gizemli niteliktedir. Bu öngörülemezlik duygusu içgüdüsel olarak korkuyu tetikleyebilir. Yaratılan sinematografik dünya görsel kodlara dönüşürken korku atmosferinin oluşmasında mekan önemli bir unsur olarak belirir. Sinemasal mekan, anlık görüntüyle dahi filmin içeriğine ilişkin bilgi vermektedir. Edinilen bilgi doğrultusunda film içine girilmekte, olaylar arasında ilişki kurulup verilmek istenen mesajlar algılanmaktadır.

"Korku ve dehşet her an ve her yerde insanın karşısına çıkabildiği gibi, mağaralar, dehlizler, yeraltı geçitleri, tekinsiz mekanlar, şatolar, kaleler, zindanlar gibi belirli mekânlarda çok daha güçlüdür. Bu yüzden ıssız, karanlık, bilinmeyen, keşfedilmeyi bekleyen birçok yer korku sinemasında mekân olarak kullanılmıştır. Seçilen yerler gizem ve bilinmezin beslendiği yerler olduğu gibi korkuyu çağrıştırmakta ve genelde insanların pek gitmek istemediği, ürktüğü yerler olarak bilinmektedir. Yeni arayışlar içinde korku sinemasında her şeyden korkulacağı gibi, her mekân da korkulan bir havaya büründürülebilmektedir. Efektlerin yardımıyla masumiyetin ve sıcaklığın temsil edildiği ev bir anda ürkütücü bir mekana dönüşebilir (Scognamillo, 1996: 151).

Yönetmen mekânı öyküsünü en iyi anlattığı şekilde kurmalı; seyirciyi inandırmak için detaylarla mekâna mümkün olduğunca gerçeklik kazandırmalıdır. İzleyicinin öykü içine girmesi, zaman ve uzam ile kurulan bağ ile ilgilidir (Yolcu, 2001: 134). Özellikle uzam seyircinin zihninde kahramanla özdeşleşip, onunla devinmesi açısından son derece önemlidir.

Korku sinemasında filmler diğer türlerde olduğu gibi doğal mekânda çekilip stüdyoda hazırlanan dekorlar ya da tamamen dijital olarak üretilmiş mekanlarla da çekilebilmektedir. Her ikisinde de önemli olan seyircinin filmin içine girip korkuyu yaşayabilmesidir. Mekân bazı görülmeyen fakat hissedilebilen duyguları saklama özelliğine sahiptir.

\subsection{Gerçeküstü mekanlar}

Farklı tarihlerde çekilmiş farklı film türlerinde gerçeküstü mekanların kullanıldığı görülmektedir. Özellikle bilimkurgu ve bilimkurgu korku türlerinde karşımıza çıkan fütürist ve zaman zaman distopik mekanlar gerçeküstü mekanlar olarak değerlendirilebilir. Bu mekanlarda günümüzde mevcut olmayan teknolojiler, inşa edilmesi imkansız yapılar, dünya yüzeyinde yer almayan mekanlar ve çevreler karşımıza çıkar.

Sinemadaki gerçeküstü mekanlar, kurgusal, ama mantıksal bir düzleme oturan simüle edilmiş mekanlardır. Edebiyatta "ütopya" kavramının ortaya çıkışının ardından sinemada da etkilerini göstermeye başlamıştır. Genellikle gerçek hayatta var olmayan, hatta olması mümkün olmayan hayalî kurgu mekânlar olduklarından sinemadaki yansımaları özellikle bilim kurgu filmlerinde görülmektedir. Kurgulanan ütopik mekanlar izleyiciye gerçek hayattan oldukça farklı koşulları, farklı bilimsel ve teknik imkânları tasvir etmektedir. Gerçeküstü mekân oluşumunu, Metropolis (1926) - (Resim 9), Matrix (1999) - (Resim 10), Inception (2010) - (Resim 11) gibi farklı zamanlarda yapılmış farklı filmlerde görmek mümkündür (Selvitop, 2017). 

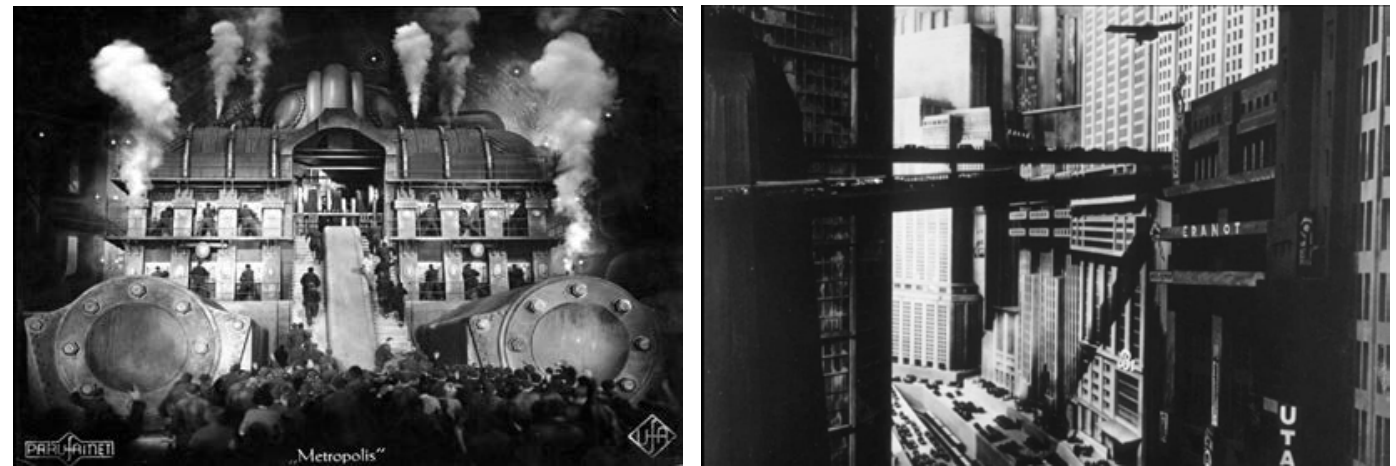

Resim 9. Metropolis (URL 14) (URL 15).
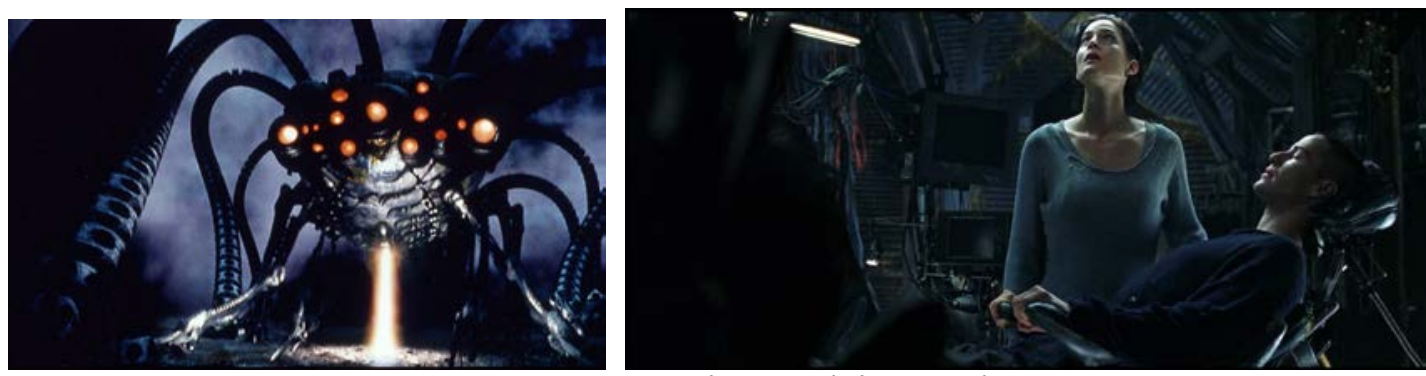

Resim 10. Matrix (URL 16) (URL 17).
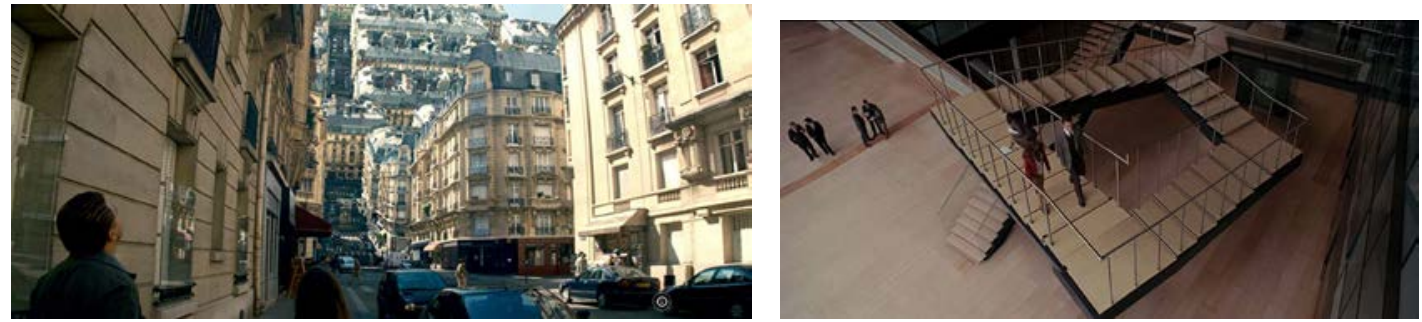

Resim 11. Inception (URL 18).

\subsection{Gerçek mekanlar}

Korku türünün popülaritesi, klasik sessiz filmlerden itibaren tüm sinema tarihini kapsar. İzleyicilerin psikolojik tepkilerine değinmeden önce korku türünün her zaman ilgi çekici olmasına neden olan belirli özelliklerini kısaca özetlemek yerinde olur. Walters (2004), tüm korku filmlerinin bir ölçüde gerilime neden olduğunu; izleyiciler için ilgi uyandıran bir gerçek dışılık hissi sergilediğini belirtir. Gerilim, neredeyse tüm korku filmi türlerinin bir özelliğidir. Bu özelliği korku filmlerinin izlenme motivasyonunu arttırıcı niteliktedir. Genel olarak, bir sorunu ve bu sorunun çözümünü içeren filmlerin izlenmesi tercih edilir (belirli bir bağlamda yaşayan belirli karakterler, çoğu durumda belirli hedeflere nasıl ulaşabilir veya ulaşamaz, engellerle nasıl başa çıkılır veya zorluklarla nasıl yüzleşilir gibi). Bununla birlikte, korku filmlerinin doğasında olan ancak gerilimden macera filmlerine, fanteziden savaş filmlerine, hepsi olmasa da pek çok filmin ortak paydası olan "gizem" yine izlenmenin artmasında önemli ögelerden biri olarak karşımıza çıkar.

Korku filmlerinde kullanılacak mekan tercihlerinden ilki, gerçek mekânlardır. Film yapımında bazı mekânlar, bütün özellikleri korunarak kullanılırken, bazı filmlerde ise mekân tamamen değiştirilerek farklı bir etki için filmin içeriğine uygun olarak düzenlenebilir. Günün koşullarına uygun olarak oyuncular, mekânı bir sahne olarak kullanabilir, mekânda var olan gerçek yaşam birebir kayıt da edilebilir. Sinema ve mimarinin ortak sorunlarından birinin mekan tasarlama olduğu görülmektedir. Ancak tasarım süreçleri değerlendirildiğinde birbirinden ayrıldıkları en önemli özelliğin 
mimaride var olan yer - zaman sınırlayıcılarının sinema mekânları için geçerli olmamasıdır. Bununla birlikte, sinemada sınır tanımayan mekân tasarlama süreci, mimaride bugün olmasa da geleceğin mekânları için ilham kaynağı olmaktadır. Mekân kavramı ve oluşum sürecine bakıldığında, mimari mekânı oluşturan fiziksel etmenlerin yanı sıra, mekana "yer duygusu" nu veren kültürel etmenler gibi soyut kavramların var olduğu görülür ve mekânı yere dönüştüren bu kavramlardır. Aynı şekilde sinemada da kültürel olgular gibi soyut kavramların mekanda somutlaşarak aktarılması söz konusudur.

Gerçek mekanların bir başka kullanımı ise; o zamanın tarihi değere sahip olan yapılarının dönem koşullarına göre kullanıldığı filmlerdir. Psyho (Resim 12) ve Vertigo (Resim 13) bu filmlere örnek olarak gösterilebilir.

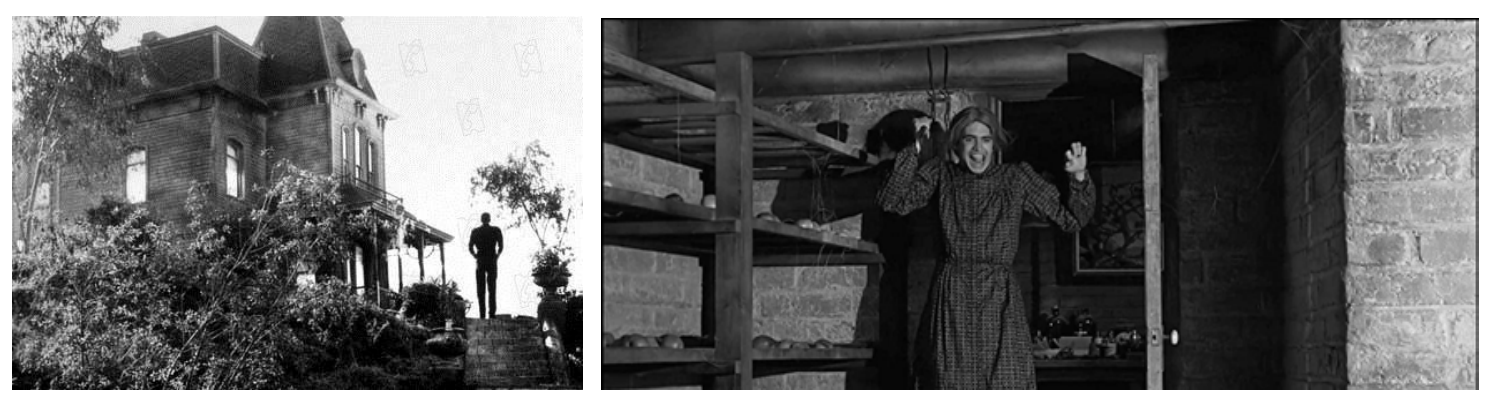

Resim 12. Psycho (URL 10) (URL 11).
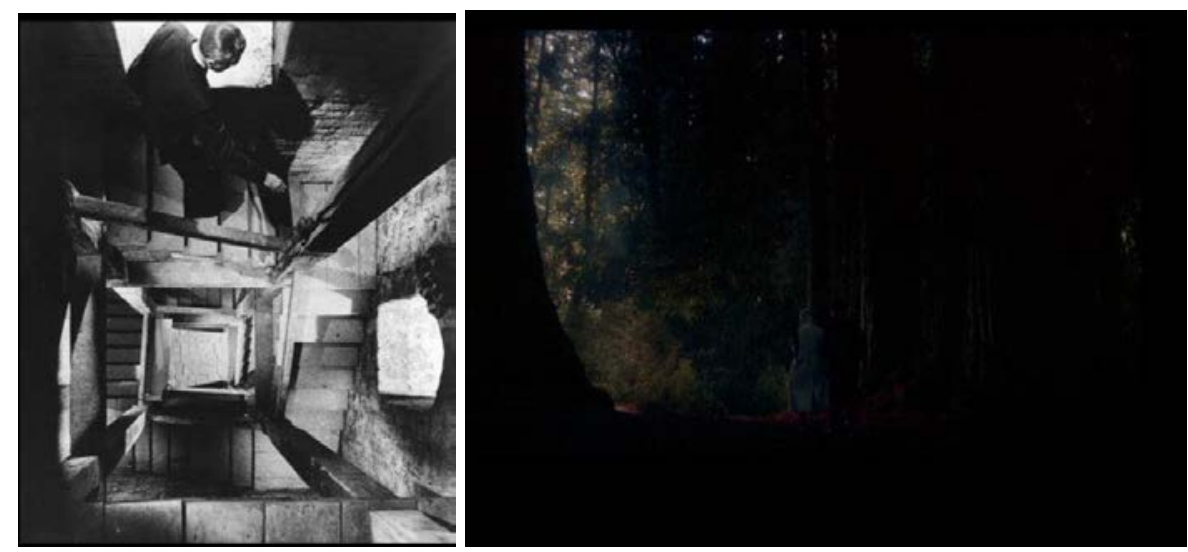

Resim 13. Vertigo (URL 12) (URL 13).

Bu tür filmlerde hem sinema yapıların tarihsel kimliklerini filmlerinde kullanır hem de izleyiciler yapıların gerçek yapılış amaçlarını görme fırsatı bulurlar. Yapılı çevrede kullanıcı algısı için ön plana çıkan öğelerin, sinema mekânlarında da algı kavramını etkileyen öğeler olduğu görülmektedir. Mevcut mekânın yeniden kurgulanmasının filmlerde sıklıkla kullanılan bir mekan kurgu yöntemi olduğu bilinmektedir. Teknoloji ile paralel ilerleyen kurgu yöntemi ise; hayali mekânların bilgisayar ortamında tasarlanması olarak tanımlanabilecek, sanal mekân kurgusudur.

Sanal mekan kurgusunda hayali mekânlar ile izleyicide gerçek mekân etkisi oluşturabilmek hedeflenmektedir (Akyıldız, 2012). 


\section{Korku Sinemasında Kullanılan Gerçek Mekanların "Session 9" (Son Seans) Filmi Üzerinden İncelenmesi}

Korku sinemasında mekân; kişilerin fobilerini ve kaygılarını tetikleyecek şekilde tasarlanmaktadır. Dış mekânın tekin olmaması, içeride sıkışma, renklerin abartılı kullanılışı, senaryoda korku durumunu oluşturan öğelerdir (Kılıç, 2017).

Korku sinemasında gerçek mekanların kullanılmasına örnek olarak seçilen "Session 9" (Son Seans) filmi, büyük bir hastanedeki temizlik işçilerinin arasında gelişen gerilimi anlatmaktadır. Brad Anderson'ın ilk korku çalışması olan bu film 2000'lerin başında var olmaya çabalayan psikolojik korku türünün örneklerinden biri olarak görülmektedir.

"Session 9" (Son Seans) filminin en büyük özelliği, mekanın kendisinin yarattığı atmosfer içindeki çirkinliği maskeleyen güzel bir mimariye sahip, terk edilmiş bir akıl hastanesinde geçiyor olmasıdır.

Filme mekan olan; 1874'de yapımına başlanan Danvers Eyalet Hastanesi, ABD'nin Massachusetts eyaletinin Danvers şehrinde bir psikiyatri hastanesidir ve 1878'de açılmıştır. Danvers daha önce Salem Köyü olarak adlandırılmış ve 1690 daki ünlü Salem Cadı Duruşmaları burada yapılmıştır. Geçmişte Salem'de yaşanan kötü olaylardan dolayı adı değiştirilmiştir (Resim 14).

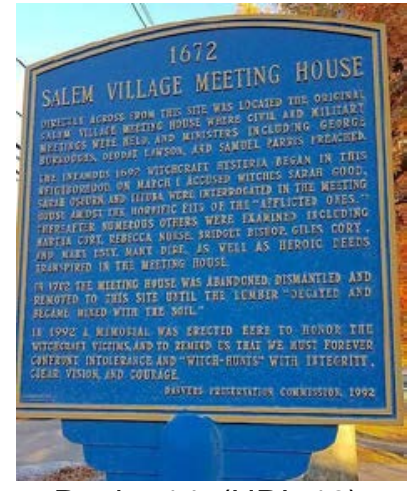

Resim 14. (URL 19).

Hastane, Kirkbride Planı kapsamında mimar Nathaniel Jeremiah Bradlee tarafından tasarlanmıştır (Resim 15, Resim 16).

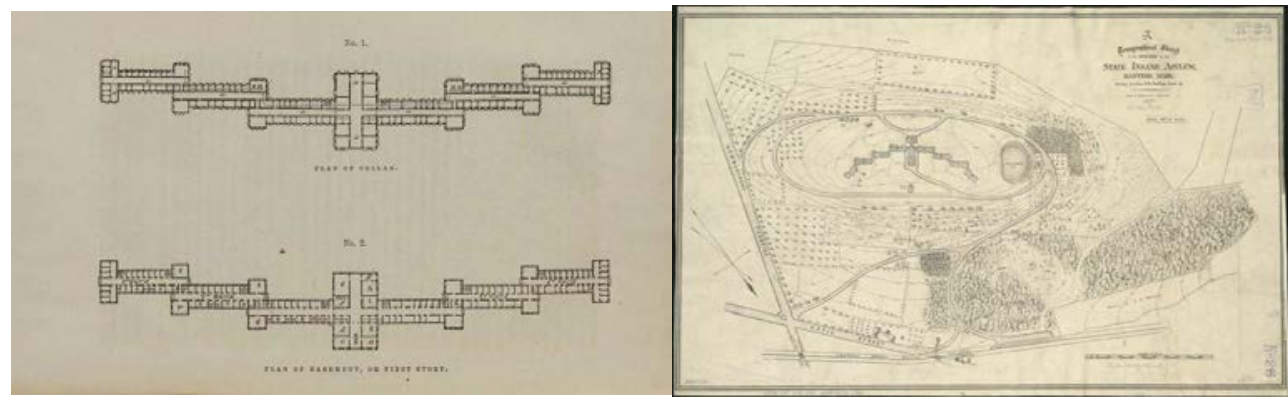

Resim 15. Kirkbride Planı (URL 20).

Resim 16. Topografik Harita (URL 21).

$\mathrm{Bu}$ tür akıl hastaneleri arasında New Jersey'deki Trenton Eyalet Hastanesi ve Massachusetts' teki Metropolitan Eyalet Hastanesi de vardır. Geniş bir kırsal alana yayılan ve başlangıçta iki ana binası olan hastanenin en büyüğü, hastaları barındıran birkaç kanat içermektedir. Batı tarafında erkeklerin doğu tarafında ise kadınların kaldığı 
hastanede en ağır hastalar, kanatların uç kısmına yerleştirilmiştir. Başlangıçta 500 hastayı barındıracak şekilde tasarlanmıştır ancak hasta sayısı 2000 e kadar yükselmiştir

Binalar bir dizi yeraltı tüneli ile birleştirilmiş ve hastanenin kendi kendine yetebileceği bir enerji üretim tesisi yerleştirilmiştir (Resim 17).

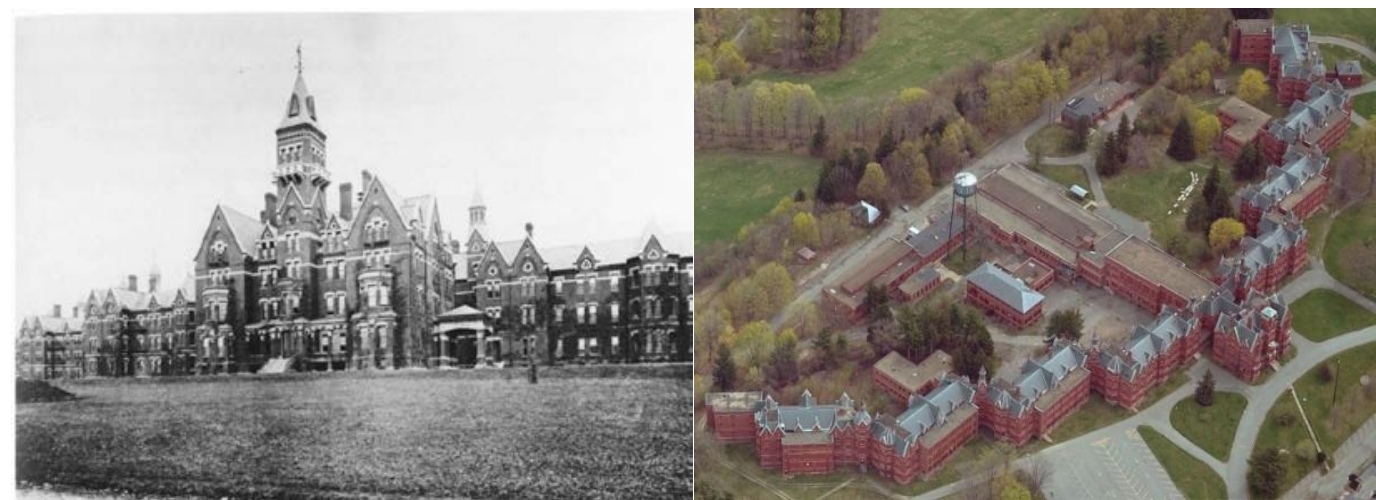

Resim 17. Danvers Akıl Hastanesi (URL 22) (URL 23).

Filmin tamamı terk edilmiş hastanenin içinde ve arazisinde inşa ettikleri küçük bir set de çekilmiştir. Çekimleri çok zor gerçekleştirilen hastaneye inandırıcılığı arttırmak için "asbest, küf ve toksik maddeler" eklenmiştir (Resim 18, Resim 19, Resim 20).
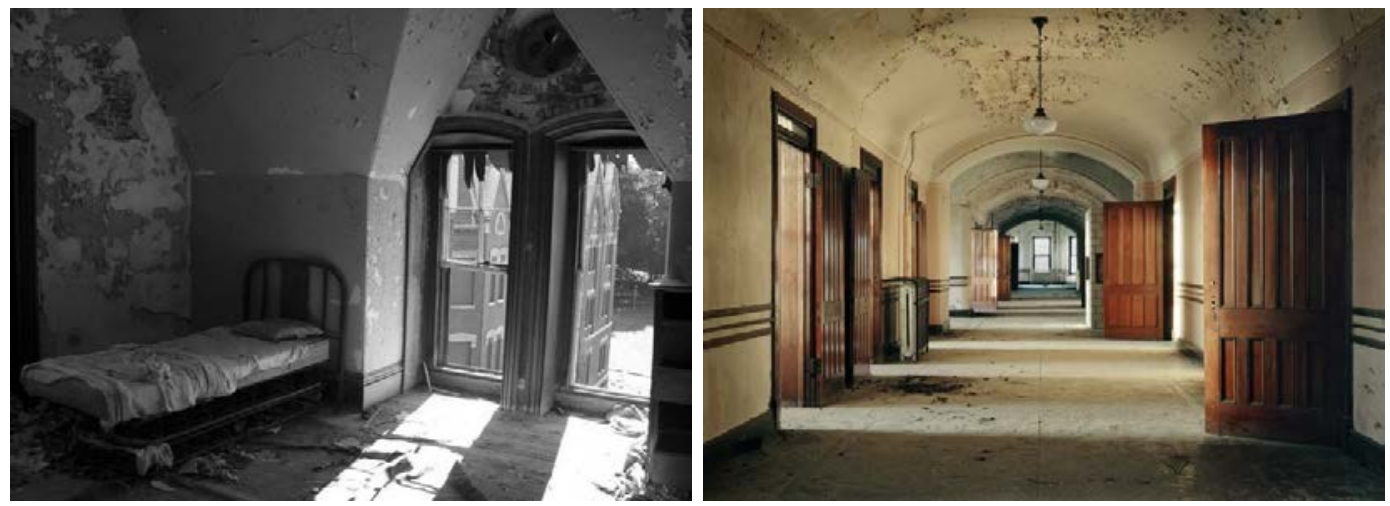

Resim 18. Danvers Akıl Hastanesi (URL 24) (URL 25).
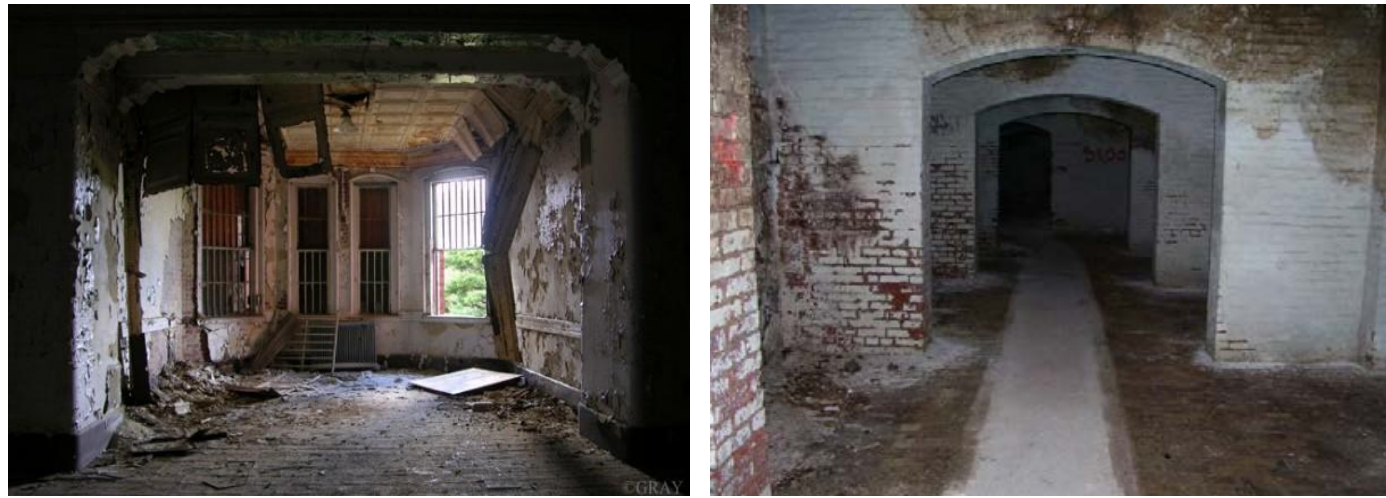

Resim 19. Danvers Akıl Hastanesi (URL 26) (URL 27). 

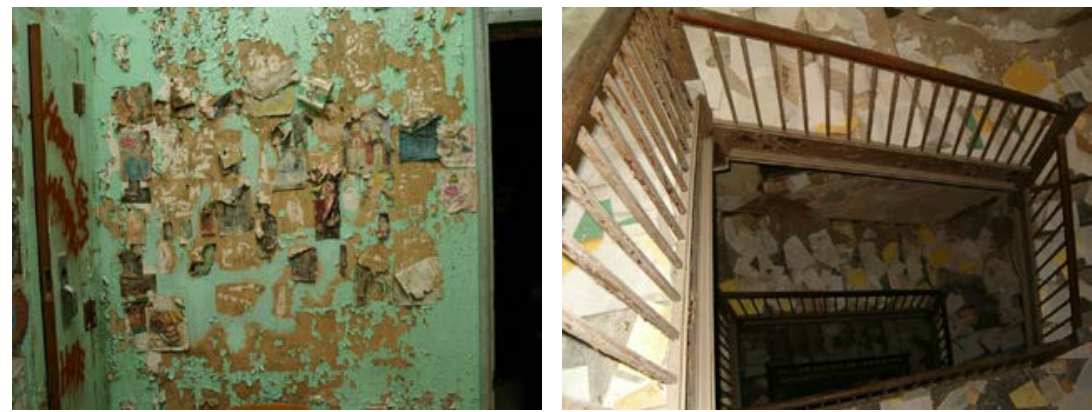

Resim 20. Danvers Akıl Hastanesi (URL 28).

Filmde görülen aksesuarların çoğu hastanede bulunmuş ve kullanılmıştır. İkonik kütüphane bile hastanenin içindeki gerçek bir mekandır. Çoğu korku filmi bir stüdyoda kendi setlerini kurgulamayı tercih ettiği için, "Session 9" (Son Seans) filmi gerçek mekanda çekilen birkaç korku filminden biridir (Resim 21).
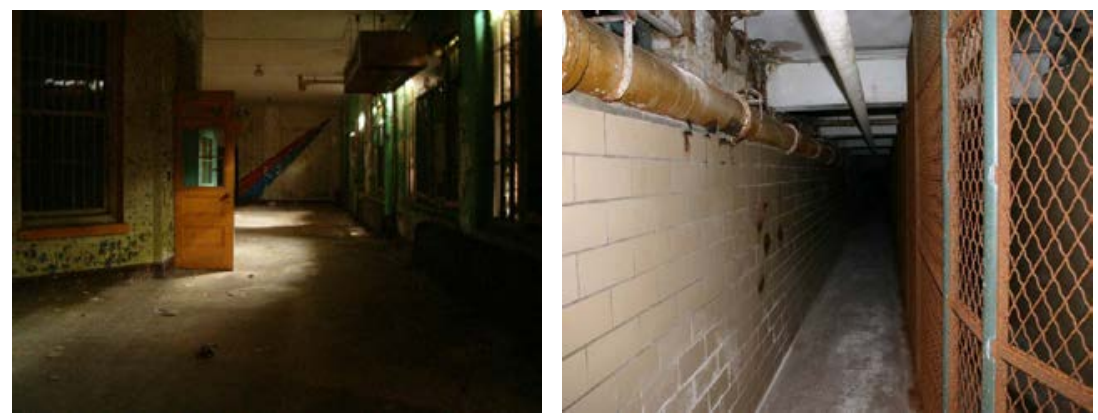

Resim 21. Danvers Akıl Hastanesi (URL 29).

1930'larda ve 1940'larda hastane çok kalabalık bir hal aldığı için yeraltı tünellerinde bile hastalar yatmaya başlamıştır. Filmde görülen mezarlık hastanenin yakınlarındaki gerçek bir mezarlıktan örnek alınarak modellenmiştir (Resim 22).
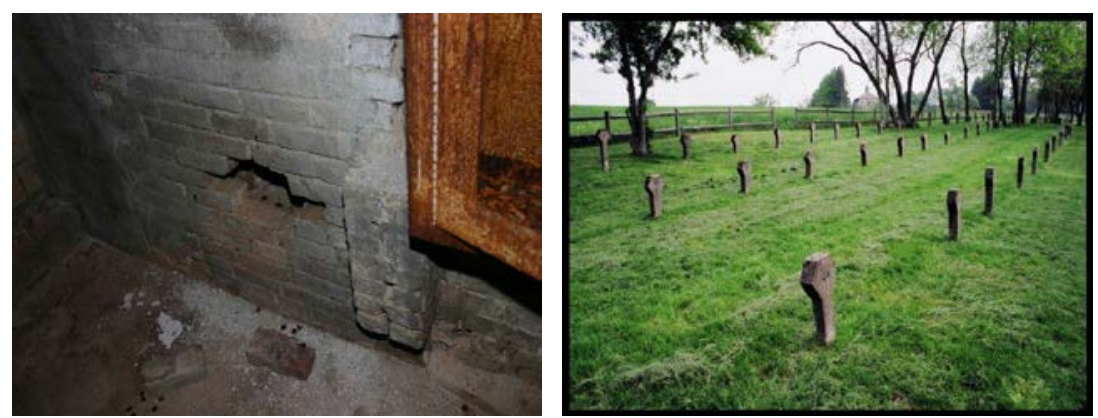

Resim 22. Danvers Akıl Hastanesi (URL 29) (URL 30).

Amerika'daki en insanlık dışı akıl hastanelerinden biri olduğu için kötü bir şöhrete sahiptir ve 1960 da hastanenin kapanmasına ilişkin yapılan açıklamada, gerçek skandalların ve sorunların olduğu söylenmiştir. 2001 yılında film çekildiğinde hastane terk edilmiş durumda olup 2006 yılında da yıkılmıştır.

İzleyiciye korku duygusunun sadece karanlık sahnelerle verileceği klişesinin yıkıldığı bu filmde, aydınlık mekanların da korku duygusunu nasıl tetiklediği gösterilmektedir. Mekanın geniş açı objektiflerle görüntülenmesi ve düzgün ses efektleriyle desteklenmesi oldukça ürkütücü bir atmosfer yaratılmasını olanaklı kılmıştır. 
Gerçek mekanların hafızaya/deneyimlemeye dayalı tanıdık olma duygusu izleyicinin filmlerdeki karakterlerle paralellik/empati kurma, kendini özdeşleştirme eğiliminde tetikleyici rol oynamakta böylece inandırıcılık düzeyini arttırmaktadır. Dolayısıyla bu gerçek olmayan ama gerçeğe oldukça paralel uzamsal algı daha kuvvetli bir korku duygusu yaratmaktadır.

Örneğin filmde karanlık korkusu olan karakterin, elektrikle aydınlatılmış uzun bir koridorda ilerlerken, bulunduğu yerden başlayarak ileriye doğru ışıkların teker teker hızla sönmesi ve karakterin ışığa doğru koştuğu sahne güçlü bir gerilim duygusu yaratmaktadır. Burada izleyici konutlarda dahi yer alan koridor (bir geçiş mekanı) mekanını özellikle çocuklukta çoğu kişide bulunan "karanlıktan korkma" ile ilişkilendirir. Bu tanıdık olma hali gerilimi yükselten temel sebeplerden biridir.

Hastaneler çoğu insan için ölüm, hastalık ve hatta fiziksel acı ile ilişkilendirilebilecek niteliktedir. Bu nedenle genellikle huzursuz/rahatsız edici oldukları söylenebilir. Hastane mekanlarının bu olumsuz algısı izleyici üzerinde oluşturulmak istenen tekinsizlik ve rahatsız edicilik için çok uygun bir sahne olmasını sağlar. Filme konu olan hastanenin terkedilmiş, harabe görünümü bu olumsuz algıyı güçlendirecek niteliktedir.

Özellikle kurgusal akıl hastaneleri, delilik fikrinin üzerine basılabileceği, korkuları ve yanlış anlamaları yeniden canlandırmak için bir dizi karakterin yerleştirilebileceği teatral bir yer sağlar. Dolayısıyla da korku, gerilim ve diğer kurgusal hikayelerde sıkça rastlanan yerler olarak karşımıza çıkarlar. Hastane fikrinin olumsuz yönü "akıl hastanesi" nin temsil ettiği kavramlarla birleşince katlanarak artar.

Böylelikle film alışılagelmiş korku/gerilim öğelerinin hiçbirini kullanmadan, tamamen mekana ait tekinsiz atmosferi ile seyircide korku duygusunu harekete geçirmeyi başarmaktadır.

\section{Sonuç}

İnsan ve mekan ayrılmaz bir bütündür. Sinemasal mekan ise fiziksel olarak deneyimlenmese dahi, her bir görüntüde yer alan, göstergeler aracılığıyla kurulmuş, kavramsallaşmış uzam aracılığıyla deneyimlenir. Bu noktada sinemasal mekan kullanım şekilleri itibariyle düşsel bir gerçeklik alanı oluşturmaya imkan tanır. Bu düşsel gerçeklik ile anlatılmak istenen hikaye yeni ve daha etkileyici bir hal alır.

"Sinemada mekân sadece fiziksel dünyanın bir parçası değil, zihinselliğin, düşselliğin, içselliğin de bir parçasıdır. Mekân sadece barınmak için var edilmiş bir fiziksel gerçeklikten ziyade, düşünceden doğan, hissedilen, bilinçaltında yer eden, var olan bir mekâna dönüşür. Zihinde başlayan bir süreç olan mimarlık eylemi de tıpkı sinema gibi, takip eden tüm evrelerinde görüntülerle düşünmeyi ve zihinsel mekân kurgularının imgelenme biçimleri üzerinden şekillenmektedir" (Tunçok Sarıberberoğlu, 2019: 37).

Sinematografik mekan filmin anlattığı konu ile birlikte şekillenerek bir "temsil mekan" halini alır. Bu bağlamda gösterilenin temel aldığı fiziksel mekanın gerçekliğinden farklıdır. Sinemasal mekan fiziksel bir gerçeklik değil, anlatılan hikayenin göstergelerinin biçimsel ve anlamsal olarak uzamsal karşılığına denk gelmektedir. Sinematografik kurgu oluşturulurken istenilen anlam yaratılmak üzere biçimlerle oynanır ve fiziksel mekan manipüle edilir. Böylelikle oluşturulan kodlar aracılığıyla izleyicinin anlam üretmesi sağlanır. Ancak izleyicinin subjektif bakış açısı; kendi yaşamsal deneyimleri anlam oluşumunu çok olasılıklı hale dönüştürür. Bu noktada 
Korku Sinemasında Mekan Algısının "Gerçek Mekan” Olgusu Üzerinden Değerlendirilmesi: Session 9 (Son Seans) Filmi Evaluation of The Perception of Space in Horror Cinema Based On The "Realistic Space" Phenomenon: Session 9 Film

gerçek fiziksel mekanlar bilinir-tanınır olma olanağı ve genel-yaygın normlarla daha kolay bağlantı kurabilme becerisi ile anlam üretme sürecinde daha isabetli mesajlar içerir. Gösterilmek istenen izleyicinin kişisel deneyimleriyle paralel niteliktedir ve çıkarımlar daha nesnel olabilir. Böylece verilmek istenen mesajın etkisi güçlenir.

Sonuç olarak yapılan çalışmada; korku filmlerinde kullanılan gerçeküstü/kurgusal mekanların aksine gerçek mekanların hafızaya dayalı tanıdık olma duygusu izleyicinin filmlerdeki karakterlerle paralellik/empati kurma, kendini özdeşleştirme eğiliminde tetikleyici rol oynamakta olduğu, böylece inandırıcılık düzeyinin artarak mesaj aktarımının güçlendiği söylenebilir.

\section{Kaynaklar}

Akbulut, D., (2012). Sinemanın İlkleri Korku Sineması, İstanbul: Etik.

Akyıldız, Ö., (2012). "Mimari Mekanların, Sinemanın Kurgusal Mekanlar Üzerine Etkileri”. Yüksek Lisans Tezi, Yıldız Teknik Üniversitesi, Fen Bilimleri Enstitüsü.

Aytekin, M., (2006). "Korku Sinemasında Vampir Filmleri ve Korku Sinemasının Tarihsel Sürecinde Değişen Vampir İmgesi”. Yüksek Lisans Tezi, İstanbul Üniversitesi, Sosyal Bilimler Enstitüsü, İstanbul.

Bak, C., (1997). Vampir ya da Öteki Olana Bakış, İstanbul: Cem Bak.

Bak, C., (2002). Aksak Sekans, İstanbul, Cem Bak.

Büker, S., (2010). Sinemada Anlam Yaratma, İstanbul: Yorum Sanat.

Carroll, N., (2005). Karabasan ve Korku Filmi: Fantastik Varlıkların Simgesel Biyolojileri (Çev: Zafer Özden), İzmir: Sinemasal, Dokuz Eylül Yayınları, Temmuz, Ağustos, Eylül2005.

Çebi, Z., (2005). Türk Sinemasında Korku Fenomeni, İstanbul: Asya.

Dönmez, M., (2018). "Türk Korku Sinemasında Sembollerin İncelenmesi ve Hasan Karacadağ Sineması”. Yüksek Lisans Tezi, İstanbul Gelişim Üniversitesi, Sosyal Bilimler Enstitüsü, İstanbul.

İlkdoğan, H., (2020). Sinematografik Mekanın Tasarımı ve Algısı, Bursa: Sapiens.

Jung, C. G., (1989). Memories, Dreams, Reflections, (Translated from The German by Richard and Clara Winston). Vintage Books.

Kılıç, O., (2017). "Korku Sinemasının İç Mekan Tercihlerine Bir Bakış”. Akademik Sosyal Araştırmalar Dergisi, 5(54), 428-432.

Köknel, Ö., (1998). Korkular, Takıntılar, Saplantılar, İstanbul: Altın Kitaplar.

Mannoni, P., (1992). Korku (Çev: Işın Gürbüz). İletişim: İstanbul.

Oskay, Ü., (1994). Çağdaş Fantazya (Popüler Kültür Açısından Bilim-Kurgu ve Korku Sineması), İstanbul: Der. 
Ross, P., (1984). "Kanlı Sinema” (Çev: Bertan Onaran). Gelişim Sinema (Aylık Sinema Video Dergisi), 1.

Tunçok Sarıberberoğlu, M., (2019). "Sinematik Kurgunun Bilinçaltı Mekanları-Tekinsiz Mekanlar”, Mimarlık ve Yaşam, 5(1), 27-39.

Scognamillo, G., (1996), s.151). "Şiddet, Toplum, Birey ve Kan", Cogito/Şiddet (Üç Aylık Düşünce Dergisi), İstanbul: Pentimento.

Selvitop, S. S., (2017). "Sinemada Kurgusal Mekan Oluşumu ve Yaratılan Mekanların Resimler Estetiği”. Yüksek Lisans Tezi, Mimar Sinan Güzel Sanatlar Üniversitesi, Fen Bilimleri Enstitüsü.

Şimşek, G., (2016). Sinemada Korku ve Din: 2000 Sonrası Amerikan ve Türk Filmlerinde Cin Unsurunun Çözümlemesi, İstanbul: Pales.

Tohill, C., ve Tombs P., (2005). Avrupa Seks ve Korku Sineması, İstanbul: Kabalcı.

Walters, G. D., (2004). "Criminal Justice and Behavior", SAGE Journals, 31(4), 516518.

Yavuz, F., (2004). "Bastırılanın Kaçınılmaz Geri Dönüşü: Korku Sineması". Sinemasal Dergisi, Dokuz Eylül Yayınları, 13.

Yolcu, E., (2001). Televizyon Reklamcılığı (Sinemanın Etkisinde Düşünsel ve Görüntüsel Yaratım Öğeleri Açısından). İstanbul: İstanbul Üniversitesi İletişim Fakültesi Yayınları.

URL1:https://alchetron.com/Roundhay-Garden-Scene\#roundh.ay-garden-scene9dc9bb74-893e-41cb-ba96-615889fb8d4-resize-750.jpg (Erişim Tarihi: 03.02.2021).

URL2:https://alchetron.com/Roundhay-Garden-Scene\#roundhay-garden-scenee5696b8c-0392-46ed-a230-62d1d3ee51f-resize-750.png (Erişim Tarihi: 07.02.2021).

URL3:https://www.amazon.com/Roundhay-Garden-Scene-Marc-Davis/dp/B00IA98T9M (Erişim Tarihi: 06.02.2021).

URL4:http://www.diazmag.com/le-manoir-du-diable-le-premier-film-dhorreur1896/\#prettyPhoto/0/ (Erişim Tarihi: 05.02.2021).

URL5:https://saude.abril.com.br/blog/uma-nerd-na-saude/frankenstein-pode-terimpedido-a-extincao-da-hu anidade/ (Erişim Tarihi: 07.02.2021).

URL6:http://www.beyazperde.com/filmler/film-2186/fotolar/detay/? cmediafile=21145654 (Erişim Tarihi: 02.02.2021).

URL7:http://www.beyazperde.com/filmler/film-2186/fotolar/detay/? cmediafile=21145643 (Erişim Tarihi: 02.02.2021).

URL8:http://www.beyazperde.com/filmler/film2342/fotolar/detay/?cmediafile=21223505 (Erişim Tarihi: 02.02.2021). 
Korku Sinemasında Mekan Algısının "Gerçek Mekan” Olgusu Üzerinden Değerlendirilmesi: Session 9 (Son Seans) Filmi Evaluation of The Perception of Space in Horror Cinema Based On The "Realistic Space" Phenomenon: Session 9 Film

URL9:http://www.beyazperde.com/filmler/film2342/fotolar/detay/?cmediafile=21223503 (Erişim Tarihi: 07.02.2021).

URL10:http://www.beyazperde.com/filmler/film1603/fotolar/detay/?cmediafile=1887596 3 (Erişim Tarihi: 07.02.2021).

URL11:https://www.imdb.com/title/tt0054215/mediaviewer/rm3577095424/(Erişim Tarihi: 06.02.2021).

URL12:https://www.imdb.com/title/tt0052357/mediaviewer/rm4101085184/(Erişim Tarihi: 06.02.2021).

URL13:https://www.imdb.com/title/tt0052357/mediaviewer/rm2714816769/(Erişim Tarihi: 01.02.2021).

URL14:https://www.imdb.com/title/tt0017136/mediaviewer/rm259390208/(Erişim Tarihi: 01.02.2021).

URL15:https://www.imdb.com/title/tt0017136/mediaviewer/rm3702848000/(Erişim Tarihi: 07.02.2021).

URL16:https://www.imdb.com/title/tt0133093/mediaviewer/rm2400749312/(Erişim Tarihi: 07.02.2021).

URL17:https://www.imdb.com/title/tt0133093/mediaviewer/rm2676260865/(Erişim Tarihi: 08.02.2021).

URL18:https://www.imdb.com/title/tt1375666/mediaviewer/rm1069515520/(Erişim Tarihi: 08.02.2021).

URL19:https://www.worldabandoned.com/danvers-state-hospital(ErişimTarihi: 07.02.2021).

URL20:https://www.onlyinyourstate.com/massachusetts/boston/creepy-asylum-boston/ (Erişim Tarihi: 07.02.2021).

URL 21: https://www.danversstatehospital.org/history (Erişim Tarihi: 07.02.2021).

URL22:https://allthatsinteresting.com/danvers-state-hospital(Erişim Tarihi: 07.02.2021).

URL 23 https://www.abandonedplaygrounds.com (Erişim Tarihi: 07.02.2021).

URL 24:https://missrosen.wordpress.com (Erişim Tarihi: 07.02.2021).

URL 25:https://urbanomnibus.net (Erişim Tarihi: 07.02.2021).

URL 26: urban-exploration.wonderhowto.com (Erişim Tarihi: 07.02.2021).

URL 27:www.paranormal-activity2.estranky.cz (Erişim Tarihi: 07.02.2021).

URL28:https://www.worldabandoned.com/danvers-state-hospital(ErişimTarihi: 07.02.2021). 
URL29:https://www.worldabandoned.com/danvers-state-hospital(ErişimTarihi: 07.02.2021).

URL30:https://www.onlyinyourstate.com/massachusetts/boston/underground-railroadboston/(Erişim Tarihi: 07.02.2021). 